\title{
PENGARUH DEBT TO EQUITY RATIO, RETURN ON EQUITY, TINGKAT SUKU BUNGA, DAN INFLASI TERHADAP RETURN SAHAM PERUSAHAAN SUBSEKTOR PROPERTY DAN REAL ESTATE YANG TERDAFTAR DI BURSA EFEK INDONESIA PERIODE 2007-2012
}

\author{
Tri Oktiar* \\ Program Studi Akuntansi Fakultas Ekonomi \\ Universitas Sarjanawiyata Tamansiswa \\ *trioktiar23@gmail.com
}

\section{INTISARI}

Penelitian ini dimaksudkan untuk menguji pengaruh Debt to Equity Ratio (DER), Return On Equity (ROE), tingkat suku bunga, dan inflasi terhadap return saham perusahaan subsektor property dan real estate yang terdaftar di Bursa Efek Indonesia. Variabel independen yang digunakan adalah Debt to Equity Ratio (DER), Return On Equity (ROE), tingkat suku bunga, inflasi dan variabel dependen return saham. Tujuan penelitian ini untuk memperoleh bukti empiris tentang pengaruh Debt to Equity Ratio (DER), Return On Equity $(R O E)$, tingkat suku bunga, dan inflasi terhadap return saham perusahaan subsektor property dan real estate yang terdaftar di Bursa Efek Indonesia.

Populasi dalam penelitian ini adalah perusahaan subsektor property dan real estate yang terdaftar di Bursa Efek Indonesia (BEI) dengan waktu amatan tahun 2007 sampai dengan tahun 2012. Data yang digunakan dalam penelitian ini diperoleh dari Indonesia Capital Market Directory (ICMD) dan Bank Indonesia. Metode analisis data yang digunakan adalah regresi linier berganda, sementara uji hipotesis menggunakan uji simultan (Uji F) untuk menguji pengaruh variabel secara bersama-sama dan uji t dengan tingkat signifikansi $5 \%$ untuk menguji pengaruh variabel secara parsial.

Berdasarkan hasil pengujian, diperoleh hasil secara simultan Debt to Equity Ratio (DER), Return On Equity (ROE), tingkat suku bunga, dan inflasi berpengaruh terhadap return saham perusahaan subsektor property dan real estate yang terdaftar di Bursa Efek Indonesia, sedangkan secara parsial Debt to Equity Ratio (DER), tingkat suku bunga, dan inflasi berpengaruh negatif dan signifikan, Return On Equity (ROE) berpengaruh positif signifikan terhadap return saham perusahaan subsektor property dan real estate. Kemampuan prediksi dari keempat variabel tersebut terhadap return saham adalah $15,5 \%$ sebagaimana ditunjukkan oleh besarnya adjusted $R^{2}$, sedangkan sisanya dipengaruhi oleh faktor lain yang tidak dimasukkan ke dalam model penelitian.

\section{Kata kunci: Return Saham, Debt to Equity Ratio (DER), Return On Equity (ROE), Tingkat Suku Bunga, Inflasi}

\section{PENDAHULUAN}

Kegiatan investasi di pasar modal merupakan suatu kegiatan menempatkan dana pada satu atau lebih aset selama periode tertentu dengan harapan dapat memperoleh pendapatan atau peningkatan atas nilai investasi awal (modal) yang bertujuan untuk memaksimalkan hasil (return) yang diharapkan dalam batas risiko yang dapat diterima untuk tiap investor (Jogiyanto,
2003:109). Return saham merupakan hasil yang diperoleh dari kegiatan investasi. Menurut Sawir (2005:4), ada dua faktor yang mempengaruhi return dalam berinvestasi, yaitu pertama adalah faktor internal perusahaan seperti kualitas manajemen, kondisi struktur dan kinerja keuangan perusahaan, dan sebagainya. Kinerja keuangan perusahaan dapat dilihat dari rasio keuangan perusahaan tersebut. Kedua adalah 
faktor eksternal, misalnya dampak kebijakan moneter dan fiskal, perkembangan sektor industri dan faktor ekonomi makro misalnya terjadinya inflasi, tingkat suku bunga Bank Indonesia dan sebagainya.

Perkembangan return saham perusahaan di industri properti mengalami fluktuasi yang cukup menarik. Berdasarkan data di Indonesia Capital Market Directory (ICMD) pada tahun 2007 return saham sektor tersebut mengalami pertumbuhan sebesar $104,87 \%$, lalu pada tahun 2008 mengalami penurunan return sebesar 120,67\% dan pada tahun 2009 mengalami pertumbuhan kembali sebesar $41,85 \%$, tahun 2010 sebesar 38,35\%, tahun 2011 sebesar 56,17\%, tahun 2012 sebesar 42,44\%. Pada tahun 2008 kondisi perekonomian global sedang terguncang hingga berdampak kepada perekonomian di Indonesia. Kondisi tersebut juga berdampak pada industri properti.

Debt to Equity Ratio (DER) menggambarkan perbandingan utang dan ekuitas dalam pendanaan perusahaan dan menunjukkan kemampuan modal sendiri perusahaan tersebut untuk memenuhi seluruh kewajibannya (Sawir, 2005:13). Semakin besar struktur hutang dalam memenuhi permodalan perusahaan, maka manajemen akan semakin gencar dalam operasional usahanya karena naiknya modal perusahaan sehingga ekspansi bisnis dan target perusahaan akan tercapai sehingga laba perusahaan pun akan ikut naik.

\section{Return On equity}

$(R O E)$

memperlihatkan sejauh mana perusahaan mengelola modal sendiri (net worth) secara efektif, mengukur tingkat keuntungan dari investasi yang telah dilakukan pemilik modal sendiri atau pemegang saham perusahaan (Sawir, 2005:20). Di industri properti, penggunaan modal sendiri yang efektif untuk membeli banyak tanah dan mengembangkannya akan memberikan dampak positif terhadap omset perusahaan tersebut.

Tingkat suku bunga merupakan salah satu variabel yang sering dipertimbangkan dalam mengambil keputusan investasi. Banyak perusahaan properti yang memiliki kondisi struktur modal perusahaan dimana komponen hutang lebih besar daripada ekuitas perusahaan. Hutang atau pinjaman yang diperoleh perusahaan properti sebagian besar berasal dari bank. Jika suku bunga acuan dari Bank Indonesia dinaikkan, maka suku bunga kredit yang dikeluarkan oleh bank umum juga akan ikut naik. Peningkatan tersebut akan berpengaruh pada biaya bunga pinjaman yang ditanggung oleh perusahaan. Kondisi tersebut juga akan berpengaruh pada kinerja perusahaan industri tersebut karena akan berdampak pada menurunnya tingkat laba.

Industri properti merupakan salah satu industri yang sensitif terhadap kondisi fluktuasi inflasi. Inflasi terjadi ditandai dengan kecenderungan naiknya harga-harga barang, sehingga berdampak pada kenaikan biaya produksi dalam industri properti, sehingga manajemen harus menaikkan harga jual produknya. Besarnya biaya produksi menyebabkan laba perusahaan akan menurun. Hal tersebut merupakan berita buruk bagi investor, sehingga investor akan melepas sahamnya dan menyebabkan harga saham menurun. Pada akhirnya, hal tersebut berpengaruh pada menurunnya return saham yang akan diperoleh oleh investor.

Penelitian ini melanjutkan penelitian dari Nini Safitri Aziz (2012). Perbedaan penelitian ini adalah variabel $R O A$ diganti dengan variabel $R O E$ dan objek penelitian yaitu perusahaan subsektor perbankan diganti dengan perusahaan subsektor property dan real estate. Alasan pemilihan subsektor property dan real estate adalah informasi tentang struktur modal perusahaan $(D E R)$ dan tingkat kemampulabaan perusahaan yang berasal dari ekuitas $(R O E)$ serta informasi tingkat suku bunga, dan inflasi diduga dapat mempengaruhi tingkat laba perusahaan properti yang pada akhirnya akan mempengaruhi return saham perusahaan tersebut dalam hal ini terdapat perubahan return saham yang fluktuatif selama periode $2007-2012$. 


\section{Rumusan Masalah}

a. Bagaimanakah pengaruh Debt To Equity Ratio, Return On Equity, tingkat suku bunga, dan inflasi secara simultan terhadap return saham perusahaan subsektor property dan real estate yang terdaftar di Bursa Efek Indonesia periode 2007-2012 ?

b. Bagaimanakah pengaruh Debt To Equity Ratio (DER) terhadap return saham perusahaan subsektor property dan real estate yang terdaftar di Bursa Efek Indonesia periode 2007-2012?

c. Bagaimanakah pengaruh Return On Equity (ROE) terhadap return saham perusahaan subsektor property dan real estate yang terdaftar di Bursa Efek Indonesia periode 2007-2012 ?

d. Bagaimanakah pengaruh tingkat suku bunga terhadap return saham perusahaan subsektor property dan real estate yang terdaftar di Bursa Efek Indonesia periode 2007-2012 ?

e. Bagaimanakah pengaruh inflasi terhadap return saham perusahaan subsektor property dan real estate yang terdaftar di Bursa Efek Indonesia periode 2007-2012?

\section{METODOLOGI PENELITIAN}

Dalam penelitian ini digunakan dua variabel, yaitu variabel dependen dan independen.
Dalam penelitian ini, variabel dependen adalah return saham yang dinyatakan dalam persen dan variabel independen adalah Debt To Equity Ratio, Return On Equity, tingkat suku bunga, dan inflasi.

\section{Sifat Penelitian}

Penelitian yang digunakan dalam penelitian ini bersifat kuantitatif, karena menggunakan data yang berbentuk angka atau data kualitatif yang diangkakan atau scoring (Sugiyono, 2013:28). Data yang berbentuk angka tersebut diperoleh dari sampel populasi penelitian dianalisis dengan metode statistik kemudian diinterprestasikan.

\section{Metode Pengumpulan Data}

Metode pengumpulan data dalam penelitian ini dilakukan dengan studi pustaka, yaitu dengan melakukan telaah pustaka, eksplorasi dan mengkaji berbagai literatur pustaka seperti jurnal, skripsi, tesis dan sumbersumber lain yang berkaitan dengan penelitian dan dokumentasi yaitu dengan mengumpulkan data dengan cara mencatat dokumen/data.

Data sekunder yang akan digunakan dalam penelitian ini adalah laporan keuangan tahunan perusahaan property dan real estate yang terdaftar di Bursa Efek Indonesia dan data tingkat suku bunga dan inflasi periode 2007-2012. Sumber data berasal dari Indonesia Capital Market Directory (ICMD) dan www.bi.go.id.

Tabel 1

Definisi Operasional Variabel

\begin{tabular}{|c|c|c|c|}
\hline No & Variabel & Definisi Variabel & Pengukuran \\
\hline 1 & $\begin{array}{l}\text { Return } \\
\text { Saham }\end{array}$ & $\begin{array}{l}\text { Tingkat pengembalian dari kegiatan } \\
\text { investasi saham yang dihitung dari } \\
\text { harga saham sekarang dikurangi harga } \\
\text { saham tahun lalu dibagi dengan harga } \\
\text { saham tahun lalu. }\end{array}$ & Persen \\
\hline 2 & $\begin{array}{l}\text { Debt to } \\
\text { Equity } \\
\text { Ratio } \\
\text { (DER) }\end{array}$ & $\begin{array}{l}\text { Rasio antara total hutang terhadap total } \\
\text { ekuitas. } \\
\text { Perhitungan rasio } D E R \text { sesuai dengan } \\
\text { rumus di laporan keuangan perusahaan } \\
\text { yang dipublikasikan. }\end{array}$ & Persen \\
\hline 3 & $\begin{array}{l}\text { Return } \\
\text { On } \\
\text { Equity }\end{array}$ & $\begin{array}{l}\text { Rasio antara laba bersih terhadap } \\
\text { ekuitas. } \\
\text { Perhitungan rasio ROE sesuai dengan }\end{array}$ & Persen \\
\hline
\end{tabular}




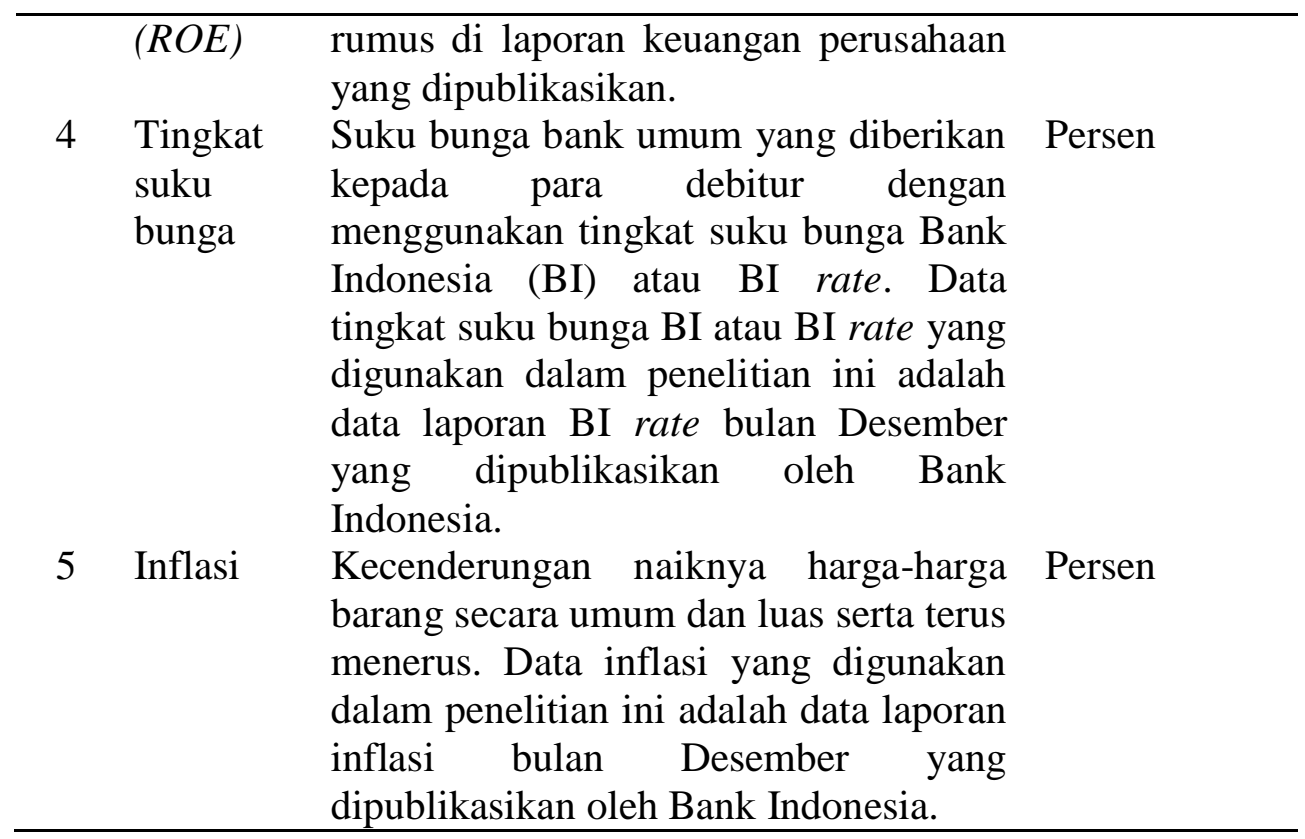

\section{Populasi, Sampel, Teknik Pengambilan Sampel}

Populasi dalam penelitian ini adalah perusahaan property dan real estate yang terdaftar di Bursa Efek Indonesia pada periode 2007-2012. Pemilihan sampel dalam penelitian ini dilakukan dengan menggunakan metode purposive sampling.
Teknik purposive sampling dilakukan dengan memilih sampel dengan tujuan tertentu secara subyektif peneliti sesuai kriteria-kriteria yang ditetapkan dan harus dipenuhi oleh sampel. Kriteria yang harus dipenuhi dalam pengambilan purposive sampling:

Tabel 2

Kriteria Perusahaan

\begin{tabular}{lc}
\hline \multicolumn{1}{c}{ Kriteria Perusahaan } & Sampel \\
\hline $\begin{array}{l}\text { Perusahaan subsektor property dan real estate yang sudah } \\
\text { listing di Bursa Efek Indonesia sebelum tahun 2007 dan }\end{array}$ & 23 \\
tidak pernah delisting hingga tahun 2012 & \\
$\begin{array}{l}\text { Perusahaan yang tidak menerbitkan laporan keuangan } \\
\text { tahunan secara lengkap }\end{array}$ & 18 \\
$\begin{array}{l}\text { Jumlah sampel perusahaan dalam } 1 \text { tahun } \\
\text { Periode pengamatan } 6 \text { tahun : } 6 \text { x 18, sehingga jumlah } \\
\text { amatan }\end{array}$ & 108 \\
\hline
\end{tabular}

\section{Teknik Analisis Data}

Dalam penelitian ini, semua data variabel ditransformasi ke bentuk log natural (Ln), karena adanya data rasio yang tidak stabil dan sangat fluktuatif dari tahun ke tahun. Tujuannya adalah untuk menstabilkan data yang bernilai sangat fluktuatif tersebut agar dapat terbebas dari penyimpangan hasil analisis. Setelah semua data variabel ditransformasikan ke dalam bentuk log natural, maka data sudah dapat di uji asumsi klasik, uji regresi, dan uji hipotesis.

\section{Uji Asumsi Klasik \\ 1) Uji Normalitas}

Metode yang dapat dipakai untuk normalitas antara lain analisis grafik dan analisis statistik. Pada prinsipnya normalitas dapat dideteksi dengan melihat penyebaran data (titik) pada sumbu diagonal dari grafik atau 
dengan melihat histogram dari residualnya (Ghozali, 2011:163). Normalitas dengan metode analisis statistik dideteksi dengan menguji normalitas residualnya pada uji nonparametrik Kolmogorov-Smirnov (K-S) (Ghozali, 2011:160)

\section{2) Uji Multikolonieritas}

Uji multikolonieritas bertujuan untuk mengetahui apakah dalam model regresi ditemukan adanya korelasi antar variabel independen (Ghozali, 2011:105). Untuk mendeteksi ada atau tidaknya multikolonieritas didalam regresi antara lain dapat dilakukan dengan melihat nilai tolerance dan lawannya serta Variance Inflation Factor (VIF)

\section{3) Uji Heteroskedastisitas}

Uji heteroskesdatisitas bertujuan untuk menguji apakah model regresi terjadi ketidaksamaan variance dari residual satu pengamatan ke pengamatan yang lain (Ghozali, 2011:139). Model regresi yang baik adalah yang homoskesdatisitas atau tidak terjadi heteroskesdatisitas.

\section{4) Uji Autokorelasi}

Model regresi yang baik adalah yang bebas autokorelasi. Untuk mendeteksi auto korelasi, dapat dilakukan uji statistik melalui Durbin-Watson (DW test). Pengambilan keputusan ada tidaknya autokorelasi sebagai berikut:

Tabel 3

Uji Autokorelasi

\begin{tabular}{lcc}
\hline \multicolumn{1}{c}{ Hipotesis nol } & Keputusan & Jika \\
\hline Tidak ada autokorelasi positif & Tolak & $0<\mathrm{d}<\mathrm{dl}$ \\
Tidak ada autokorelasi positif & No decision & $\mathrm{dl} \leq \mathrm{d} \leq \mathrm{du}$ \\
Tidak ada autokorelasi negatif & Tolak & $4 \mathrm{du}<\mathrm{d}<4$ \\
Tidak ada autokorelasi negatif & No decision & $4-\mathrm{du} \leq \mathrm{d} \leq 4 \quad \mathrm{dl}$ \\
Tidak ada autokorelasi, positif & Tidak & $\mathrm{du}<\mathrm{d}<4-\mathrm{du}$ \\
atau negatif & ditolak & \\
\hline
\end{tabular}

\section{Analisis Regresi}

Penelitian ini bertujuan menguji pengaruh hubungan antara variabel-variabel independen terhadap variabel dependen dengan menggunakan analisis regresi linier berganda. Statistik untuk menguji hipotesis dalam penelitian ini menggunakan metode regresi linier berganda dengan rumus:

$$
Y=\alpha+b_{1} x_{1}+b_{2} x_{2}+b_{3} x_{3}+b_{4} x_{4}+e
$$

\section{Keterangan:}

$\begin{array}{ll}Y & : \text { Return saham } \\ b_{1}, b_{2}, b_{3}, b_{4} & : \text { konstanta persamaan regresi } \\ x_{1} & : \text { Debt to Equity Ratio }(D E R) \\ x_{2} & : \text { Return On Equity }(\text { ROE }) \\ x_{3} & : \text { Tingkat suku bunga } \\ x_{4} & : \text { Inflasi } \\ e & : \text { standard error }\end{array}$

\section{Uji Hipotesis}

1) Uji Determinasi $\left(\mathbf{R}^{2}\right)$

Uji determinasi $\left(R^{2}\right)$ pada intinya mengukur seberapa jauh kemampuan model dalam menerangkan variasi variabel dependen (Ghozali, 2011:97). Nilai $R^{2}$ berkisar $0<\mathrm{R}^{2}<1$, semakin besar $\mathrm{R}^{2}$ maka variabel bebas semakin dekat hubungannya dengan variabel tidak bebas, dengan kata lain model tersebut dianggap baik.

\section{2) Uji Pengaruh Simultan (Uji F)}

Pengujian ini bertujuan untuk mengetahui apakah variabel-variabel independen secara simultan atau bersamasama mempengaruhi variabel dependen secara signifikan (Ghozali, 2011:98). Uji ini dapat dilakukan dengan syarat: 
a) Jika $\mathrm{F}$ hitung < $\mathrm{F}$ tabel, maka $\mathrm{H} 0$ terdukung, yaitu variabel-variabel independen secara simultan tidak berpengaruh terhadap variabel dependen.

b) Jika F hitung > F tabel, maka H0 tidak terdukung, yaitu variabel-variabel independen secara simultan berpengaruh terhadap variabel dependen.

\section{3) Uji Statistik t}

Uji statistik $t$ pada dasarnya menunjukkan seberapa jauh pengaruh satu variabel penjelas secara individual dalam menerangkan variabel terikat (Ghozali, 2011:98). Pengujian ini dilakukan dengan uji-t atau t-test, yaitu membandingkan antar t-hitung dengan t-tabel. Uji ini dilakukan dengan syarat :

a) Jika t-tabel < t-hitung, maka $\mathrm{H} 0$ terdukung yaitu variabel independen tidak berpengaruh signifikan terhadap variabel dependen.

b) Jika t-hitung $>$ t-tabel atau t-hitung-ttabel, maka H0 tidak terdukung yang berarti variabel independen berpengaruh signifikan terhadap variabel dependen.

\section{HASIL DAN PEMBAHASAN \\ Statistik Deskriptif Variabel}

Tabel 4

Descriptive Statistics (Data Asli)

\begin{tabular}{llrrrr}
\hline & N & \multicolumn{1}{c}{ Minimum } & \multicolumn{1}{c}{ Maximum } & \multicolumn{1}{c}{ Mean } & \multicolumn{1}{c}{ Std. Deviation } \\
\hline debt to equity ratio & 108 & .05 & 6.32 & 1.0291 & .98901 \\
return on equity & 108 & -58.25 & 33.13 & 6.0998 & 9.38805 \\
tingkat suku bunga & 108 & 5.75 & 9.25 & 7.0000 & 1.23897 \\
inflasi & 108 & 2.78 & 11.08 & 5.9167 & 2.75678 \\
return saham & 108 & -89.80 & 1624.14 & 74.5913 & 202.64375 \\
Valid N (listwise) & 108 & & & & \\
\hline
\end{tabular}

Berdasarkan tabel statistik deskriptif data asli dapat dilihat bahwa data valid $\mathrm{N}$ sebanyak 108 waktu amatan.

Tabel 5

Descriptive Statistics (Data Ln)

\begin{tabular}{lrrrrr}
\hline & N & \multicolumn{1}{c}{ Minimum } & Maximum & \multicolumn{1}{c}{ Mean } & \multicolumn{1}{c}{ Std. Deviation } \\
\hline LnDER & 108 & -3.00 & 1.84 & -.4175 & 1.02799 \\
LnROE & 98 & -2.30 & 3.50 & 1.5552 & 1.20276 \\
LnSB & 108 & 1.75 & 2.22 & 1.9314 & .16796 \\
LnInflasi & 108 & 1.02 & 2.41 & 1.6741 & .45632 \\
LnRS & 70 & -.17 & 4.24 & 2.7288 & .90003 \\
Valid N & 66 & & & & \\
(listwise) & 66 & & & \\
\hline
\end{tabular}

Berdasarkan tabel statistik deskriptif data Ln dapat dilihat bahwa data valid N sebanyak 66 waktu amatan. Berkurangnya sampel dari 108 menjadi 66 tidak mempengaruhi hasil yang pengujian. Penyebab berkurangnya sampel karena ada data yang bernilai negatif pada data asli sehingga ketika ditransformasi ke dalam bentuk log natural (Ln) data tersebut tereliminasi. Data yang tereliminasi tersebut ada pada variabel $R O E$ dan return saham masing-masing berkurang menjadi 98 dan 70 . 


\section{JURNAL AKUNTANSI. VOL.2 NO.2 DESEMBER 2014}

\section{Uji Asumsi Klasik}

a) Uji Normalitas

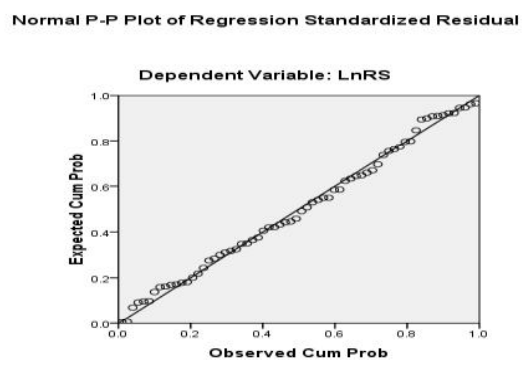

Berdasarkan gambar Normal P-P Plot of Regression Standardized Residual menunjukkan pola data terdistribusi normal, terlihat titik-titik menyebar disekitar garis diagonal dan mengikuti arah garis diagonal, maka model regresi memenuhi asumsi normalitas.

Tabel 6

One-Sample Kolmogorov-Smirnov Test

\begin{tabular}{llr}
\hline & & Unstandardized Residual \\
\hline $\mathrm{N}$ & & 66 \\
Normal & Mean & .0000000 \\
Parameters & a & Std. Deviation \\
Most & Absolute & .81892007 \\
Extreme & Positive & .069 \\
Differences & Negative & .043 \\
Kolmogorov-Smirnov Z & -.069 \\
Asymp. Sig. (2-tailed) & .558 \\
\hline a. Test distribution is Normal. & .915 \\
\hline
\end{tabular}

Berdasarkan tabel One sample KolmogorovSmirnov Test dapat dilihat nilai probabilitas (signifikansi) yang ditunjukkan pada Asymp. Sig. (2-tailed) sebesar 0,915. Nilai probabilitas (signifikansi) tersebut lebih dari 0,05 maka seluruh data variabel dalam penelitian ini terdistribusi secara normal.

\section{b) Uji Multikolonieritas}

\begin{tabular}{|c|c|c|}
\hline \multirow[b]{3}{*}{ Model } & $\begin{array}{l}\text { Tabel } 7 \\
\text { Coefficients }^{a}\end{array}$ & \\
\hline & Collinearity Statistics & \\
\hline & Tolerance & VIF \\
\hline \multicolumn{3}{|c|}{1 (Constant) } \\
\hline LnDER & .687 & 1.456 \\
\hline LnROE & .592 & 1.690 \\
\hline LnSB & .432 & 2.314 \\
\hline LnInflasi & .510 & 1.959 \\
\hline
\end{tabular}

a. Dependent Variable: LnRS

Berdasarkan tabel Coefficients multikolonieritas tersebut dapat dilihat bahwa nilai tolerance dan VIF dari variabel debt to equity ratio (LnDER) adalah sebesar 0,687 dan 1,456 dan variabel return on equity (LnROE) sebesar 0,592 dan 1,690. Untuk variabel tingkat suku bunga (LnSB) sebesar 0,432 dan 2,314 dan variabel inflasi (LnInflasi) sebesar 0,510 dan 1,959. Oleh karena itu, dapat disimpulkan bahwa tidak ada multikolineritas antar variabel independen dalam model regresi karena nilai tolerance $\quad 0,10$ dan nilai $\mathrm{VIF} \leq 10$. 


\section{c) Uji Heteroskesdatisitas}

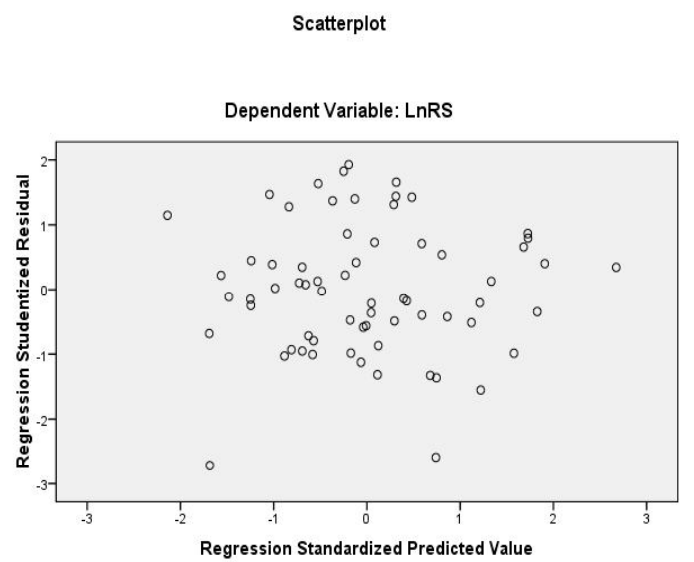

Berdasarkan gambar Scatter Plot tersebut terlihat bahwa titik-titik menyebar secara acak serta tersebar di atas maupun di bawah angka 0 pada sumbu Y. Hal ini berarti tidak terjadi heteroskidastisitas pada model regresi, sehingga model regresi layak dipakai untuk prediksi pengaruh return saham berdasarkan masukan Debt to Equity Ratio (DER), Return On Equity (ROE), tingkat suku bunga, dan inflasi.

\section{d) Uji Autokorelasi}

Tabel 8

Model Summary ${ }^{b}$

\begin{tabular}{lcccrr}
\hline Model & $\mathrm{R}$ & $\mathrm{R}$ Square & $\begin{array}{c}\text { Adjusted R } \\
\text { Square }\end{array}$ & $\begin{array}{c}\text { Std. Error of the } \\
\text { Estimate }\end{array}$ & Durbin-Watson \\
1 & $.455^{\mathrm{a}}$ & .207 & .155 & .84534 & 1.888 \\
\hline a. Predictors: (Constant), LnInflasi, LnDER, LnROE, LnSB \\
\multicolumn{5}{l}{ b. Dependent Variable: LnRS }
\end{tabular}

Berdasarkan tabel Model Summary tersebut dapat diketahui bahwa nilai Durbin-Watson 1,888 lalu hasil ini dibandingkan dengan nilai $d l$ dan $d u$ pada tabel Durbin-Watson. Penelitian ini menggunakan jumlah sampel 66, dengan variabel independen 4, maka berdasarkan tabel Durbin Watson diperoleh nilai $d u$ sebesar 1,7319 dan $d l 1,4758$. Syarat penelitian untuk dapat dinyatakan bebas autokorelasi adalah $d u<d<(4-d u)$, dari hasil nilai hitung tersebut diperoleh hasil $1,7319<1,888<2,2681$, maka tidak terjadi autokorelasi pada model regresi yang digunakan dalam penelitian ini.

\section{Analisis Regresi Berganda}

Tabel 9

Analisis Regresi Berganda Coefficients $^{a}$

\begin{tabular}{|c|c|c|c|c|c|}
\hline \multirow[b]{2}{*}{ Model } & \multicolumn{2}{|c|}{$\begin{array}{l}\text { Unstandardized } \\
\text { Coefficients }\end{array}$} & \multirow{2}{*}{$\begin{array}{c}\text { Standardized } \\
\text { Coefficients } \\
\text { Beta }\end{array}$} & \multirow[b]{2}{*}{$\mathrm{t}$} & \multirow[b]{2}{*}{ Sig. } \\
\hline & B & Std. Error & & & \\
\hline 1 (Constant) & -3.866 & 2.020 & & -1.914 & .060 \\
\hline LnDER & -.427 & .130 & -.452 & -3.285 & .002 \\
\hline LnROE & .415 & .126 & .490 & 3.306 & .002 \\
\hline LnSB & -3.778 & 1.197 & -.547 & -3.157 & .002 \\
\hline LnInflasi & -.887 & .396 & -.357 & -2.239 & .029 \\
\hline
\end{tabular}

Berdasarkan tabel Coefficients analisis maka dapat disusun persamaan regresi regresi berganda tersebut dengan berganda sebagai berikut:

memperhatikan angka yang berada pada LnRS = -3,866 - 0,427 $\mathbf{X}_{\mathbf{1}}+\mathbf{0 , 4 1 5} \mathbf{X}_{\mathbf{2}}$ kolom Unstandardized Coefficient Beta, $\mathbf{3 , 7 7 8} \mathbf{X}_{\mathbf{3}}-\mathbf{0 , 8 8 7} \mathbf{X}_{\mathbf{4}}$ 
Dari persamaan regresi di atas maka dapat disimpulkan sebagai berikut:

a) Nilai konstanta persamaan regresi tersebut adalah sebesar -3,866. Angka tersebut menunjukkan return saham yang diperoleh oleh investor bila $\operatorname{LnDER}\left(\mathrm{X}_{1}\right), \operatorname{LnROE}\left(\mathrm{X}_{2}\right), \operatorname{LnSB}\left(\mathrm{X}_{3}\right)$, dan LnInflasi $\left(\mathrm{X}_{4}\right)$ dianggap konstan.

b) Variabel Debt to Equity Ratio (LnDER) memiliki nilai koefisien regresi yang negatif yaitu sebesar 0,427. Nilai koefisien negatif menunjukkan bahwa Debt to Equity Ratio (DER) terhadap return saham berpengaruh negatif. Hal ini menggambarkan bahwa jika terjadi kenaikan Debt to Equity Ratio (DER) sebesar $1 \%$, maka return saham yang diperoleh turun sebesar 0,427 dengan asumsi variabel independen lain dianggap konstan.

c) Variabel Return On Equity (LnROE) memiliki nilai koefisien regresi yang positif yaitu sebesar 0,415 . Nilai koefisien positif menunjukkan bahwa Return On Equity (ROE) terhadap return saham berpengaruh positif. Hal ini menggambarkan bahwa jika terjadi kenaikan Return On Equity (ROE) sebesar $1 \%$, maka return saham yang diperoleh naik sebesar 0,415 dengan asumsi variabel independen lain dianggap konstan.

d) Variabel tingkat suku bunga (LnSB) memiliki nilai koefisien regresi yang negatif yaitu sebesar -3,778. Nilai koefisien negatif menunjukkan tingkat suku bunga terhadap return saham berpengaruh negatif. Hal ini menggambarkan bahwa jika terjadi kenaikan tingkat suku bunga sebesar $1 \%$, maka return saham yang diperoleh turun sebesar 3,778 dengan asumsi variabel independen lain dianggap konstan.

e) Variabel inflasi (LnInflasi) memiliki nilai koefisien regresi yang negatif yaitu sebesar $-0,887$. Nilai koefisien negatif menunjukkan tingkat suku bunga terhadap return saham berpengaruh negatif. Hal ini menggambarkan bahwa jika terjadi kenaikan inflasi sebesar $1 \%$, maka return saham yang diperoleh turun sebesar 0,887 dengan asumsi variabel independen lain dianggap konstan.

\section{Uji Hipotesis}

\section{a. Uji Determinasi $\left(\mathbf{R}^{2}\right)$}

Tabel 10

Model Summary ${ }^{\text {b }}$

\begin{tabular}{llrrrr}
\hline Model & $\mathrm{R}$ & $\mathrm{R}$ Square & \multicolumn{1}{c}{$\begin{array}{c}\text { Adjusted } \mathrm{R} \\
\text { Square }\end{array}$} & $\begin{array}{c}\text { Std. Error of the } \\
\text { Estimate }\end{array}$ & Durbin-Watson \\
1 & $.455^{\mathrm{a}}$ & .207 & .155 & .84534 & 1.888 \\
\hline
\end{tabular}

a. Predictors: (Constant), LnInflasi, LnDER, LnROE, LnSB

b. Dependent Variable: LnRS

Dari tabel Model Summary tersebut dapat diketahui bahwa nilai adjusted $R^{2}$ adalah 0,155 . Hal ini menunjukkan bahwa sebesar $15,5 \%$ return saham dipengaruhi oleh variasi dari keempat variabel independen yang digunakan, yaitu Debt to Equity Ratio (LnDER), Return On Equity (LnROE), tingkat suku bunga (LnSB), dan inflasi
(LnInflasi), sedangkan sisanya sebesar $84,5 \%$ dipengaruhi oleh faktor-faktor lain, seperti rasio likuiditas, rasio aktivitas, rasio penilaian pasar, dan faktor makro lain, seperti neraca perdagangan, nilai tukar mata uang, dan tingkat pertumbuhan ekonomi yang tidak dimasukkan dalam model penelitian ini. 


\section{b. Uji Pengaruh Simultan (Uji F)}

Tabel 11

ANOVA $^{\text {D }}$

\begin{tabular}{lrrrrrr}
\hline Model & Sum of Squares & df & & Mean Square & F & Sig. \\
\hline 1 Regression & 11.402 & 4 & 2.850 & 3.989 & & $.006^{\mathrm{a}}$ \\
Residual & 43.591 & 61 & .715 & & & \\
Total & 54.993 & 65 & & & & \\
\hline
\end{tabular}

a. Predictors: (Constant), LnInflasi, LnDER, LnROE, LnSB

b. Dependent Variable: LnRS

Pada tabel Anova tersebut menunjukkan angka hasil pengujian model menghasilkan $\mathrm{F}$ hitung sebesar 3,989, sementara nilai pada tabel distribusi nilai $\mathrm{F}$ dengan derajat bebas (4:66) pada taraf signifikansi 5\% adalah 2,522615. Oleh karena F hitung 3,989 > F tabel 2,522615, maka hipotesis pertama terdukung dengan tingkat signifikansi 0,006 (jauh lebih kecil dari 0,05) artinya antara Debt to Equity Ratio (LnDER), Return On
Equity (LnROE), tingkat suku bunga (LnSB), dan inflasi (LnInflasi) secara simultan berpengaruh signifikan terhadap return saham. Dengan demikian, debt to equity ratio $(D E R)$, return on equity (ROE), tingkat suku bunga, dan inflasi dapat digunakan sebagai pertimbangan utama investor dalam berinvestasi guna memperoleh return saham pada perusahaan subsektor property dan real estate.

\section{c. Uji Statistik t}

Tabel 12

Coefficients $^{a}$

\begin{tabular}{|c|c|c|c|c|c|}
\hline \multirow[b]{2}{*}{ Model } & \multicolumn{2}{|c|}{$\begin{array}{l}\text { Unstandardized } \\
\text { Coefficients }\end{array}$} & \multirow{2}{*}{$\begin{array}{c}\text { Standardized } \\
\text { Coefficients } \\
\text { Beta }\end{array}$} & \multirow[b]{2}{*}{$t$} & \multirow[b]{2}{*}{ Sig. } \\
\hline & $\mathrm{B}$ & Std. Error & & & \\
\hline 1 (Constant) & -3.866 & 2.020 & & -1.914 & .060 \\
\hline LnDER & -.427 & .130 & -.452 & -3.285 & .002 \\
\hline LnROE & .415 & .126 & .490 & 3.306 & .002 \\
\hline LnSB & -3.778 & 1.197 & -.547 & -3.157 & .002 \\
\hline LnInflasi & -.887 & .396 & -.357 & -2.239 & .029 \\
\hline
\end{tabular}

a. Dependent Variable: LnRS

\section{1) Uji pengaruh Debt to Equity Ratio} (DER) terhadap return saham.

Berdasarkan pengujian parsial (Uji t) diperoleh hasil bahwa Debt to Equity Ratio (LnDER) berpengaruh negatif dan signifikan terhadap return saham. Hal ini ditunjukkan dengan nilai t hitung sebesar -3,285 dengan tingkat signifikansi 0,002 , nilai t hitung $<\mathrm{t}$ tabel $(-3,285<1,999624)$, maka apabila Debt to Equity Ratio (DER) meningkat maka return saham yang diperoleh menurun. Peningkatan beban perusahaan terhadap kreditur akan menunjukkan sumber modal perusahaan sangat tergantung dari pihak eksternal, sehingga mengurangi minat investor dalam menanamkan dananya pada perusahaan. Penurunan minat tersebut akan berdampak pada turunnya harga saham sehingga mempengaruhi return saham.

Berdasarkan data perbandingan antara ratarata total hutang dan ekuitas seluruh perusahaan subsektor property dan real estate dengan tahun pengamatan dari 2007 sampai dengan 2012 masing-masing sebesar Rp1.452.482.067.166,- dan Rp1.260.704.042.931,- menunjukkan bahwa struktur modal dalam perusahaan properti lebih besar berasal dari pinjaman. Hal ini menyebabkan beban untuk menanggung pokok pinjaman dan bunga perusahaan lebih tinggi dibanding dengan tingkat kemampulabaan perusahaan, karena dampak 
dari ketidakseimbangan antara manfaat dan biaya dalam hal ini biaya pokok pinjaman dan bunga lebih tinggi dibanding manfaat yang diperoleh dari timbulnya hutang sehingga menyebabkan menurunnya tingkat laba perusahaan yang pada akhirnya berdampak pada menurunnya return saham yang diperoleh pemegang saham.

Menurut Arifin (2005:89) sering kali ketika kondisi kesulitan keuangan (financial distress) pada perusahaan properti terjadi akibat kegagalan dalam melakukan pembayaran utang. Proporsi utang yang tinggi menyebabkan fixed payment yang tinggi pula sehingga risiko kebangkrutan juga akan tinggi. Oleh karena itu, jika terjadi kumulatif hutang bunga dalam jangka panjang lebih besar dibanding kemampulabaan perusahaan, maka investor akan melepas sahamnya karena perusahaan tersebut dinilai sangat berisiko untuk bangkrut (collapse).

\section{2) Uji pengaruh Return On Equity (ROE) terhadap return saham}

Berdasarkan pengujian parsial (Uji-t) diperoleh hasil bahwa Return On Equity (LnROE) berpengaruh positif dan signifikan terhadap return saham. Hal ini ditunjukkan dengan nilai $t$ hitung sebesar 3,306 dengan tingkat signifikansi 0,002 dan nilai t hitung > t tabel $(3,306>1,999624)$, maka apabila Return On Equity (ROE) meningkat, maka return saham yang diperoleh juga meningkat.

Adanya pengaruh signifikan $R O E$ terhadap harga saham mengindikasikan bahwa kinerja perusahaan properti semakin efisien dalam menggunakan modal sendiri untuk menghasilkan laba atau keuntungan bersih. Peningkatan laba tersebut dapat meningkatkan profitabilitas perusahaan yang berasal dari ekuitas perusahaan.

Jika profitabilitas perusahaan properti yang berasal dari ekuitas tinggi, maka akan meningkatkan minat investor terhadap saham perusahaan tersebut. Investor menganggap perusahaan tersebut mempunyai prospek yang baik dalam meningkatkan laba. Hal tersebut yang menjadi pertimbangan utama calon investor maupun investor sebelum melakukan pembelian saham. Peningkatan minat atau permintaan (demand) calon investor maupun investor terhadap saham perusahaan tersebut menyebabkan harga saham tersebut akan meningkat, alhasil return saham yang diperoleh juga akan meningkat.

\section{3) Uji pengaruh tingkat suku bunga terhadap return saham}

Berdasarkan pengujian parsial (Uji t) diperoleh hasil bahwa tingkat suku bunga (LnSB) berpengaruh signifikan negatif terhadap return saham. Hal ini ditunjukkan dengan nilai t hitung sebesar -3,157 dengan tingkat signifikansi 0,002 , nilai $\mathrm{t}$ hitung $<\mathrm{t}$ tabel $(-3,157<1,999624)$, maka apabila tingkat suku bunga meningkat, maka return saham yang diperoleh menurun.

Berdasarkan perbandingan antara ratarata total hutang dan ekuitas seluruh perusahaan subsektor property dan real estate dengan tahun pengamatan dari 2007 sampai dengan 2012 masing-masing sebesar Rp 1.452.482.067.166,- dan Rp 1.260.704.042.931,- menunjukkan bahwa struktur modal dalam perusahaan properti lebih besar berasal dari pinjaman. Hal ini menyebabkan beban untuk menanggung pokok pinjaman dan bunga perusahaan lebih tinggi dibanding dengan tingkat kemampulabaan perusahaan.

Perusahaan subsektor property dan real estate memiliki komponen struktur modal perusahaan dalam hal ini hutang lebih besar daripada ekuitas perusahaan, sehingga perusahaan menanggung biaya bunga hutang yang besar. Hutang atau pinjaman yang diperoleh perusahaan properti adalah sebagian besar berasal dari pinjaman bank. Jika suku bunga acuan dari Bank Indonesia dinaikkan, maka suku bunga kredit yang dikeluarkan oleh bank umum juga akan ikut naik. Peningkatan tersebut akan berpengaruh pada biaya bunga pinjaman yang ditanggung oleh perusahaan. Kondisi tersebut juga akan berpengaruh pada kinerja perusahaan tersebut, karena akan berdampak pada menurunnya tingkat laba. Dalam keadaan 
tersebut, investor akan menganggap investasi saham di perusahaan properti tidak menguntungkan sehingga investor melepas sahamnya.

\section{4) Uji pengaruh inflasi terhadap return saham}

Berdasarkan pengujian parsial (Uji t) diperoleh hasil bahwa inflasi (LnInflasi) berpengaruh signifikan negatif terhadap return saham. Hal ini ditunjukkan dengan nilai t hitung sebesar -2,239 dengan tingkat signifikansi 0,029, nilai t hitung < t tabel ($2,239<1,999624)$, maka apabila inflasi meningkat maka return saham yang diperoleh menurun.

Inflasi yang tinggi akan mengakibatkan penurunan harga saham, karena menyebabkan kenaikan harga barang secara umum. Kenaikan harga-harga tersebut juga akan berdampak pada kenaikan biaya produksi dalam industri properti, sehingga manajemen harus menaikkan harga jual produknya. Kenaikan besarnya biaya produksi menyebabkan laba perusahaan akan menurun. Bagi investor, hal tersebut adalah berita buruk. Investor akan melepas saham yang dimiliki ketika terjadi inflasi tinggi. Banyaknya saham yang dilepas menyebabkan harga saham menurun, sehingga pada akhirnya return saham juga akan menurun.

Ekspektasi laju inflasi yang tinggi akan mendorong masyarakat untuk mengalihkan aset finansial yang dimilikinya menjadi aset riil, seperti emas dan barang-barang konsumsi lainya. Begitu pula sebaliknya, ekspektasi laju inflasi yang rendah akan memberikan insentif terhadap masyarakat untuk menabung serta melakukan investasi pada sektor-sektor produktif.

\section{KESIMPULAN DAN SARAN Kesimpulan}

a. Berdasarkan persamaan regresi berganda, nilai konstanta persamaan adalah sebesar -3,866. Angka tersebut menunjukkan return saham perusahaan property dan real estate yang terdaftar di Bursa Efek Indonesia periode 20072012 yang diperoleh oleh investor bila debt to equity ratio (DER), return on equity (ROE), tingkat suku bunga, dan inflasi dianggap konstan.

b. Berdasarkan pengujian secara simultan, variabel-variabel independen yang ada berpengaruh secara bersamasama terhadap variabel dependen. Hal ini ditunjukkan dengan hasil pengujian model nilai $\mathrm{F}$ hitung 3,989 > F tabel 2,522615, dengan tingkat signifikansi 0,006 (lebih kecil dari 0,05). Oleh karena $\mathrm{F}$ hitung lebih besar dari $\mathrm{F}$ tabel maka Ha terdukung dan H0 tidak terdukung, dengan demikian antara debt to equity ratio (DER), return on equity (ROE), tingkat suku bunga, dan inflasi berpengaruh secara simultan terhadap return saham perusahaan property dan real estate yang terdaftar di Bursa Efek Indonesia periode 20072012.

c. Berdasarkan pengujian secara parsial, debt to equity ratio (DER), tingkat suku bunga, dan inflasi memiliki pengaruh signifikan negatif terhadap return saham, sedangkan return on equity (ROE) memiliki pengaruh signifikan positif terhadap return saham perusahaan property dan real estate yang terdaftar di Bursa Efek Indonesia periode 2007-2012.

d. Hasil Adjusted $R$ Square dari model regresi dalam penelitian ini menunjukkan bahwa variabel-variabel independen yang mampu menjelaskan return saham sebesar $15,5 \%$, sedangkan sisanya sebesar $84,5 \%$ disebabkan oleh faktor lain di luar model yang tidak dimasukkan dalam penelitian ini, seperti rasio likuiditas, rasio aktivitas, rasio penilaian pasar, dan faktor makro lain, seperti neraca perdagangan, nilai tukar mata uang, dan tingkat pertumbuhan ekonomi.

\section{Implikasi}

Berdasarkan perhitungan analisis regresi, variabel yang memiliki pengaruh 
signifikan terhadap return saham perusahaan subsektor property dan real estate adalah debt to equity ratio (DER), return on equity $(R O E)$, tingkat suku bunga, dan inflasi, maka variabel tersebut dalam penelitian ini menjadi variabel yang dapat dijadikan acuan untuk menilai kemampuan perusahaan dalam memperoleh laba. Hal tersebut berguna bagi investor sebagai pertimbangan dalam penilaian kinerja perusahaan dalam memperoleh laba dan keputusan membeli saham perusahaan subsektor property dan real estate. Ekspektasi investor dalam pembelian saham tersebut akan berdampak pada perubahan harga saham dan pada akhirnya juga akan berdampak pada return saham yang diperoleh investor.

\section{Saran}

a. Bagi industri properti disarankan untuk mengevaluasi komposisi struktur modal perusahaan, dalam perusahaan properti rata-rata sumber dana diperoleh dari pinjaman. Evaluasi tersebut dilakukan agar perusahaan tidak terlalu terbebani dengan biaya pokok pinjaman dan bunga pinjaman ketika terjadi financial distress.

b. Bagi pihak calon investor dan investor, berdasarkan penelitian ini bahwa variabel debt to equity ratio (DER), return on equity (ROE), tingkat suku bunga, dan inflasi menunjukkan pengaruh yang signifikan terhadap return saham, maka calon investor dan investor yang akan berinvestasi saham di industri property dan real estate agar mempertimbangkan nilai debt to equity ratio (DER), return on equity ( $R O E$ ), tingkat suku bunga, dan inflasi yang dipublikasikan oleh Bursa Efek Indonesia dan Bank Indonesia dalam memulai berinvestasi saham perusahaan subsektor property dan real estate yang terdaftar di Bursa Efek Indonesia, karena variabel-variabel tersebut secara empiris terbukti mempengaruhi return saham.

c. Bagi peneliti selanjutnya disarankan untuk memperbanyak sampel yang digunakan agar hasilnya lebih baik serta menambah periode penelitian.

\section{Keterbatasan Penelitian}

Dalam penelitian ini hanya menggunakan variabel debt to equity ratio $(D E R)$, return on equity (ROE), tingkat suku bunga, dan inflasi sebagai indikator untuk mengetahui pengaruh return saham perusahaan subsektor property dan real estate, sementara masih banyak faktor-faktor lain yang mempengaruhi penelitian ini, seperti rasio likuiditas, rasio aktivitas, rasio penilaian pasar, dan faktor makro lain, seperti neraca perdagangan, nilai tukar mata uang, dan tingkat pertumbuhan ekonomi.

\section{DAFTAR PUSTAKA}

A. Diulio, Eugene. 1989. Teori Makroekonomi. Jakarta. Erlangga.

Agus dan Martono. 2005. Manajemen Keuangan. Yogyakarta. Ekonisia.

Annajihi, Ahmad. 2009. Analisis Pengaruh Price Earning Ratio (PER), Current Ratio, Total Asset Turn Over, Net Profit Margin, dan Debt Equity Ratio Terhadap Tingkat Keuntungan Saham (Studi Kasus Pada Perusahaan Sektor Property Tahun 2005-2007). Skripsi: Universitas Islam Negeri Syarif Hidayatullah Jakarta. Dipublikasikan.

Arifin, Zaenal. 2005. Teori Keuangan \& Pasar Modal. Yogyakarta. Ekonisia.

Ath Thobarry, Achmad. 2009. Analisis Pengaruh Nilai Tukar, Suku Bunga, Laju Inflasi, dan Pertumbuhan GDP Terhadap Indeks Harga Saham Sektor Properti (Kajian Empiris di Bursa Efek Indonesia Periode Pengamatan Tahun 2000-2008). Tesis: Universitas Diponegoro Semarang. Dipublikasikan.

Boediono. 1985. Pengantar Ilmu Ekonomi No. 2, Ekonomi Makro. Yogyakarta. BPFE.

Firmansyah, Erry. 2010. Metamorfosa Bursa Efek. Jakarta. PT Bursa Efek Indonesia. 
Ghozali, Imam. 2011. Aplikasi Analisis Multivariate dengan Program IBM SPSS 19. Semarang. Badan Penerbit Universitas Diponegoro.

Hendra dan Diyah. 2011. Analisis Rasio Keuangan Dalam Memprediksi Perubahan Laba Pada Perusahaan Real Estate dan Property di Bursa Efek Indonesia (BEI) dan Singapura (SGX). Jurnal: STIE Perbanas volume 1 Surabaya. Dipublikasikan.

Harahap, Sofyan Syafri. 2002. Analisa Kritis Atas Laporan Keuangan. Jakarta. PT Raja Grafindo Persada.

Hermuningsih, Sri. 2012. Pengantar Pasar Modal Indonesia. Yogyakarta. UPP STIM YKPN.

Hijriah, Almas. 2007. Pengaruh Faktor Fundamental dan Risiko Sistematik Terhadap Harga Saham Properti di Bursa Efek Jakarta. Tesis: Universitas Sumatera Utara Medan. Dipublikasikan.

Indonesia Capital Market Directory tahun 2007-2012

Insukindro. 1993. Ekonomi Uang dan Bank Teori dan Pengalaman di Indonesia. Yogyakarta. BPFE.

Iswardono. 1999. Uang dan Bank, Edisi Empat. Yogyakarta. BPFE.

Jogiyanto. 2003. Teori Portofolio dan Analisis Investasi, Edisi Ketiga. Yogyakarta. BPFE.

Naryoto, Pambuko. 2013. Pengaruh Return On Equity (ROE), Current Ratio (CR), Debt to Equity Ratio (DER), Total Asset Turnover (TATO), dan Earning Per Share (EPS) Terhadap Return Saham. Jurnal: Universitas Budi Luhur Jakarta. Dipublikasikan.

Prihantini, Ratna. 2009. Analisis Pengaruh Inflasi, Nilai Tukar, ROA, DER dan CR Terhadap Return (Studi Kasus Saham Industri Real Estate and
Property Yang Terdaftar Di Bursa Efek Indonesia Periode 2003 - 2006). Tesis: Universitas Diponegoro Semarang. Dipublikasikan.

Rusdin. 2006. Pasar Modal Teori, Masalah, dan Kebijakan dalam Praktik. Bandung. CV Alfabeta.

Safitri Aziz, Nini. 2012. Pengaruh Return On Asset (ROA), Debt to Equity Ratio (DER), Tingkat Suku Bunga, dan Tingkat Inflasi terhadap Return Saham Sektor Perbankan di Bursa Efek Indonesia (Periode 2003-2010). Skripsi: Universitas Hasanuddin Makasar. Dipublikasikan.

Sartono, Agus. 2001. Manajemen Keuangan Teori dan Aplikasi, Edisi Keempat. Yogyakarta. BPFE.

Sawir, Agnes. 2005. Analisis Kinerja Keuangan dan Perencanaan Keuangan Perusahaan. Jakarta. PT Gramedia Pustaka Utama.

Sekaran, Uma. 2010. Metode Penelitian untuk Bisnis. Jakarta. Salemba Empat.

Sugiyono. 2013. Metode Penelitian Manajemen. Bandung. CV Alfabeta.

Sunariyah. 2003. Pengantar Pengetahuan Pasar Modal, Edisi Ketiga. Yogyakarta. UPP AMP YKPN.

Susilo D, Bambang.2009. Pasar Modal Mekanisme Perdagangan Saham, Analisis Sekuritas, dan Strategi Investasi di BEI. Yogyakarta. UPP STIM YKPN.

Tandelilin, Eduardus. 2001. Analisis Investasi dan Manajemen Portofolio. Yogyakarta. BPFE.

Undang-Undang Republik Indonesia Nomor 8 tahun 1995 tentang Pasar Modal.

www.idx.co.id diakses tanggal 26 Februari 2014 pukul 10.00

www.bi.go.id diakses tanggal 20 Februari 2014 pukul 14.00 